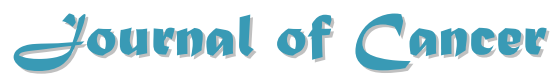

2010; 1:136-140

Mini-Review

(C) Ivyspring International Publisher. All rights reserved

\title{
Functional Mechanisms for Human Tumor Suppressors
}

\author{
Wanpeng Sun and Jian Yang ${ }^{凶}$
}

Drug Design and Discovery Research Group, College of Pharmacy and Nutrition, University of Saskatchewan, 110 Science Place, Saskatoon, Saskatchewan S7N 5C9, Canada

$\triangle$ Corresponding author: jian.yang@usask.ca

Received: 2010.08.13; Accepted: 2010.09.13; Published: 2010.09.15

\begin{abstract}
Tumor suppressors refer to a large group of molecules that are capable of controlling cell division, promoting apoptosis, and suppressing metastasis. The loss of function for a tumor suppressor may lead to cancer due to uncontrolled cell division. Because of their importance, extensive studies have been undertaken to understand the different functional mechanisms of tumor suppressors. Here, we briefly review the four major mechanisms, inhibition of cell division, induction of apoptosis, DNA damage repair, and inhibition of metastasis. It is noteworthy that some tumor suppressors, such as $\mathrm{p} 53$, may adopt more than one mechanism for their functions.
\end{abstract}

Key words: Cell division, apoptosis, metastasis, DNA repair, p53

\section{Introduction}

Cancer cells are basically transformed from normal cells (1). The transformation usually requires genetic mutations in proto-oncogenes and/or tumor suppressors (1). These mutations can be directly induced by specific cancer-causing agents such as radiations, chemicals, hormones, viruses and genetic factors (2). After transformation, the cancer cells lose their ability to control cell division, but still maintain certain characteristics of the cells from which they are derived. Tumor suppressors prevent cancer by reliably controlling cell division, promoting apoptosis, and suppressing metastasis (3). Once a tumor suppressor becomes inactive, cell division may proceed out of control and this may lead to cancer. Tumor suppressors affect both the initiation and the development of cancer, and generally follow the classic "two-hit" model (3-5). They are encoded by two alleles because chromosomes are paired in humans (3). If one allele becomes mutated (heterozygosis) or underexpressed, the other can still express the appropriate tumor suppressor to inhibit cell division (5). When both alleles are mutated or underexpressed, the inhibition of cell division is reduced and even lost (5). However, there are also exceptions, such as tumor suppressor p27. The production of p27 from the unmutated allele is not sufficient enough to bring the cell to its original condition in the heterozygote, and the cell mitosis can only be arrested when both alleles are unmutated (6).

\section{Mechanisms of Tumor Suppression}

Many tumor suppressors have activity in both normal and tumor cells; whereas the others, such as p53, are inactive in normal cells and only activated by potential cancer risks. A tumor suppressor may possess multiple mechanisms to suppress cancer cell growth (3). For example, the most important tumor suppressor p53, which is associated with about $50 \%$ of human cancer cases (7), can trigger DNA repair processes, induce the transcription of other tumor suppressors, such as p21 and p16, and initiate cell apoptosis $(3,8,9)$. Despite the tremendous growth in cancer research and identification of numerous tumor 
suppressors (10), the exact underlying mechanisms through which the tumor suppressors function are not always clearly revealed. To date, four major mechanisms have been revealed for tumor suppressors: suppression of cell division, induction of apoptosis, DNA damage repair and inhibition of metastasis.

\section{Suppression of Cell Division}

Suppression of cell division is the main mechanism for most tumor suppressors. The tumor suppressors that adopt this mechanism include retinoblastoma protein $(\mathrm{Rb})$, adenomatosis polyposis coli (APC), alternate reading frame (ARF), RIZ1, p15, p16, p18, p19, p21, p27, and p53 $(8,9,11-21)$. Rb, which is the first discovered tumor suppressor, inhibits the transcription of specific genes required for mitosis through binding to transcription factors such as E2Fs, which are key cell proliferation regulators $(12,13)$. Tumor suppressor p53, which can also bind to DNA, stimulates the expression of other genes, such as WAF1/CIP1 encoding p21 $(8,22)$. APC stabilizes microtubules to inhibit mitosis (15) and interferes with cell adhesion to its growing matrix (23). The interference with cell adhesion results in indirect suppression of cell division due to contact inhibition. It has been observed that a few tumor suppressors may act in cooperation to inhibit cell mitosis (3). Tumor suppressors p15, p16, p18, p19, p21 and p27 inhibit cyclin-dependent kinases (CDKs), which, in turn, inhibit $\mathrm{Rb}(11,24)$. When CDKs are inhibited, $\mathrm{Rb}$ is kept active to suppress cell division (24). ARF is capable of relocating the murine double minute (MDM2), a critical negative regulator of p53 inhibitor, into nuclei to activate cellular p53 (25). In addition, epigenetic regulation may play a role in tumor suppressing actions. Histone methyltransferases are recently deemed as a special group of tumor suppressors, which can directly inhibit mitosis via changing the conformation of histone to block double-strand DNA unwinding (26).

\section{Induction of Apoptosis}

Apoptosis, or programmed cell death, is another functional mechanism of tumor suppression. Examples of this group of tumor suppressors are p53, APC, cluster of differentiation 95 (CD95), bridging integrator 1 (Bin1) and phosphatase and tensin homolog (PTEN) (27-31). Unlike premature cell death, apoptosis maintains normal homeostasis and suppresses cancer $(32,33)$. It is regulated by many different pathways integrating both positive and negative regulations (34). p53 mediates apoptosis through two major pathways, the extrinsic pathway, which activates a caspase cascade including caspase- $9,-3,-6$ and -7 , and the intrinsic pathway, which promotes the apoptosome formation via the Bcl-2 family $(28,35)$. APC, which has been observed to be frequently mutated in colorectal cancer, promotes transcription-independent apoptosis via caspase 8 (27). The APC-mediated apoptosis can be abolished by caspase-8 inhibitor Z-IETD-FMK (27). CD95 is overexpressed in cancer cells and acts as an important receptor for cell death $(29,36)$. Upon being recognized immunogenically by a specific ligand expressed in the cytotoxic T killer cells, CD95 initiates apoptosis in the cancer cells (37). Bin1, which is a cell death agent, mediates apoptosis to suppress cancer by c-Myc (30). In contrary to the above discussed tumor suppressors that directly induce apoptosis, PTEN utilizes an alternative mechanism to promote apoptosis. It inactivates phosphatidylinositol 3,4,5-triphosphate (PIP3), which is important for anti-apoptosis and aids in cancer cell survival (31). Although some tumor suppressors can both inhibit mitosis and induce apoptosis, apoptosis is not necessarily induced by the inhibition of mitosis (38).

\section{DNA Damage Repair}

The tumor suppressors that can help in DNA damage repair include mutS homolog 2 (MSH2), mutL homolog 1 (MLH1), Ataxia-telangiectasiamutated gene product (ATM), breast cancer protein (BRCA), Nijmegen breakage syndrome 1 (NBS1), Fanconi-Anemia-related tumor suppressor (FA), and p53 $(3,39-43)$. They are able to fix DNA damages, including mismatch and vast damage to one of the DNA double strands. Generally, p53 can induce nucleotide excision repair to remove damaged DNA portions and mediate synthesis from the other strand; whereas MSH2 and MLH1 can repair DNA mismatch $(3,39,40)$. ATM is a general sensor to DNA damage and phosphorylates p53, BRCP, NBS1 and FA to activate the DNA repair process $(3,41)$. BRCA and p53 work together in nucleotide excision repair of DNA adducts (42). NBS1 and FA make DNA resistant to crosslinking, and may amplify the phosphorylation signal from ATM (43). In addition, thymine-DNA glycosylase (TDG) is proposed as a tumor suppressor candidate (44-46). Previous studies have shown that 5-methylation of cytosine could lead to spontaneous hydrolytic deamination to produce the $\mathrm{C} \rightarrow \mathrm{T}$ transition mutation and T-G mismatches (44-46). TDG recognizes the T-G mismatch, removes the mismatched $\mathrm{T}$ through hydrolysis of its $\mathrm{N}$-glycosidic bond, and initiates a nucleotide excision repair (44-46). The $\mathrm{C} \rightarrow \mathrm{T}$ transition mutation happens frequently in human tumors and counts for about $24 \%$ of p53 mutations (44, 47-50). Recently, TDG was shown to be a co-activator of p53 (51). 


\section{Inhibition of Metastasis}

The majority of cancer death is caused by metastasis (52). During metastasis, tumor cells have signal interactions with endothelial cells to initiate angiogenesis and break down vascular walls. These actions promote their spread. Tumor suppressors that can inhibit metastasis consist of metastin, breast cancer metastasis suppressor 1 (BRMS1), tissue inhibitor of metalloproteinase (TIMP), cofactor required for specificity protein 1 activation (CRSP), and KAL1/CD82 (53-64). The binding of metastin to the metastin receptor (orphan $\mathrm{G}$ protein-coupled receptor GPR54) increases the expression and activity of focal adhesion kinase (FAK) and inhibits the metastasis of melanoma cells (53). It has also been shown that metastin triggers phospholipase $\mathrm{C}$ activation, arachidonic acid release and extracellular signal-regulated kinase (ERK) phosphorylation in Chinese hamster ovary $(\mathrm{CHO})$ cells overexpressing metastin receptor $(54,55)$. BRMS1 regulates gene transcription through interaction with the mSin3 histone deacetylase (HDAC) complex (57). TIMPs can bind not only all matrix metalloproteinases (MMPs) in their active forms but also MMP-2 and MMP-9 in their latent forms. TIMPs reduce cancer metastasis by inhibiting the cancer cell-released MMPs, maintaining the integrity of extracellular matrices, and preventing the penetration of cancer cells through the base membrane of blood vessels (58-60). CRSP can up-regulate the expression of metastin (61). CD82 is a cell surface glycoprotein activated by p53 $(62,63)$. The expression levels of CD82 and p53 are strongly correlated (63). The exact mechanism for CD82 to inhibit cancer metastasis is still unclear; however, it may inhibit cancer cell migration/invasion through the FAK-Lyn-p130CAS_CrkII pathway (64).

\section{Summary}

In summary, we briefly reviewed the four major functional mechanisms for human tumor suppressors. Some tumor suppressors, such as p53, may utilize more than one mechanism for their suppressing functions. Recent progress in structural and functional studies of tumor suppressors and their interactions with other molecules has benefited the design and discovery of novel anticancer agents. For example, quite a few CDK inhibitors have been developed and some are already in clinical trials.

\section{Acknowledgements}

This work was supported by a research grant from the Cancer Research Society Inc. of Canada. We would also like to thank Dr. Jane Acorn of the College of Pharmacy and Nutrition, University of Saskatchewan for valuable comments and suggestions.

\section{Conflict of Interest}

The authors have declared that no conflict of interest exists.

\section{References}

1. Weinberg RA. The biology of cancer. New York, USA: Garland Science; 2007.

2. American Cancer Society. Cancer Facts and Figures. Atlanta, USA: American Cancer Society; 2008.

3. Sherr CJ. Principles of Tumor Suppression. Cell 2004; 116: 235-46.

4. Evan G, Littlewood T. A Matter of Life and Cell Death. Science 1998; 281: 1317-22.

5. Knudson AG Jr. Mutation and cancer: statistical study of retinoblastoma. Proc Natl Acad Sci USA 1971; 68: 820-3.

6. Fero ML, Randel E, Gurley KE, Roberts JM, Kemp CJ. The murine gene $\mathrm{p} 27 \mathrm{Kip} 1$ is haplo-insufficient for tumour suppression. Nature 1998; 396: 177-80.

7. Cadwell C, Zambetti GP. The effects of wild-type p53 tumor suppressor activity and mutant p53 gain-of-function on cell growth. Gene 2001; 277: 15-30.

8. Wang TJ, Huang MS, Hong CY, Tse V, Silverberg GD, Hsiao M. Comparisons of tumor suppressor p53, p21, and p16 gene therapy effects on glioblastoma tumorigenicity in situ. Biochem Biophys Res Commun 2001; 287: 173-80.

9. Levine AJ, Finlay CA, Hinds PW. P53 is a tumor suppressor gene. Cell 2004; 116: S67-9.

10. Lane DP, Hupp TR. Drug discovery and p53. Drug Discov Today 2003; 8: 347-55.

11. Sherr CJ. Cancer cell cycles. Science 1996; 274: 1672-7.

12. Vandel L, Nicolas E, Vaute O, Ferreira R, Ait-Si-Ali S, Trouche D. Transcriptional repression by the retinoblastoma protein through the recruitment of a histone methyltransferase. Mol Cell Biol 2001; 21: 6484-94.

13. Müller H, Helin K. The E2F transcription factors: key regulators of cell proliferation. Biochim Biophys Acta 2000; 1470: M1-12.

14. Bertwistle D, Sugimoto M, Sherr CJ. Physical and functional interactions of the Arf tumor suppressor protein with nucleophosmin/B23. Mol Cell Biol 2004; 24: 985-96.

15. Green RA, Wollman R, Kaplan KB. APC and EB1 function together in mitosis to regulate spindle dynamics and chromosome alignment. Mol Biol Cell 2005; 16: 4609-22.

16. He L, Yu JX, Liu L, Buyse IM, Wang MS, Yang QC, Nakagawara A, Brodeur GM, Shi YE, Huang S. RIZ1, but not the alternative RIZ2 product of the same gene, is underexpressed in breast cancer, and forced RIZ1 expression causes G2-M cell cycle arrest and/or apoptosis. Cancer Res 1998; 58: 4238-44.

17. Hannon GJ, Beach D. p15INK4B is a potential effector of TGF-beta-induced cell cycle arrest. Nature 1994; 371: 257-61.

18. Lukas J, Parry D, Aagaard L, Mann DJ, Bartkova J, Strauss M, Peters G, Bartek J. Retinoblastoma-protein-dependent cell-cycle inhibition by the tumour suppressor p16. Nature 1995; 375: 503-6.

19. Hirai H, Roussel MF, Kato JY, Ashmun RA, Scherr CJ. Novel INK4 proteins, p19 and p18, are specific inhibitors of the cyclin D-dependent kinases CDK4 and CDK6. Mol Cell Biol 1995; 15: 2672-81.

20. Harper JW, Adami GR, Wei N, Keyomarsi K, Elledge SJ. The p21 Cdk-interacting protein Cip1 is a potent inhibitor of G1 cyclin-dependent kinases. Cell 1993; 75: 805-16. 
21. Tomoda K, Kubota Y, Kato J. Degradation of the cyclin-dependent-kinase inhibitor p27Kip1 is instigated by Jab1. Nature 1999; 398: 160-5.

22. Vaziri C, Saxena S, Jeon Y, Lee C, Murata K, Machida Y, Wagle N, Hwang DS, Dutta A. A p53-dependent checkpoint pathway prevents rereplication. Mol Cell 2003; 11: 997-1008.

23. Fearnhead NS, Britton MP, Bodmer WF. The ABC of APC. Hum Mol Genet 2001; 10: 721-33.

24. Chim CS, Fung TK, Liang R. Disruption of INK4/CDK/Rb cell cycle pathway by gene hypermethylation in multiple myeloma and MGUS. Leukemia 2003; 17: 2533-5.

25. Sherr CJ, Weber JD. The ARF/p53 pathway. Curr Opin Genet Dev 2000; 10: 94-9.

26. Kim KC, Huang S. Histone methyltransferases in tumor suppression. Cancer Biol Ther 2003; 2: 491-9.

27. Steigerwald K, Behbehani GK, Combs KA, Barton MC, Groden J. The APC tumor suppressor promotes transcription-independent apoptosis in vitro. Mol Cancer Res 2005; 3: 78-89.

28. Shen Y, White E. p53-dependent apoptosis pathways. Adv Cancer Res 2001; 82: 55-84.

29. Muschen M, Warskulat U, Beckmann MW. Defining CD95 as a tumor suppressor gene. J Mol Med 2000; 78: 312-25.

30. DuHadaway JB, Sakamuro D, Ewert DL, Prendergast GC. Bin1 mediates apoptosis by c-Myc in transformed primary cells. Cancer Res 2001; 61: 3151-6.

31. Simpson L, Parsons R. PTEN: life as a tumor suppressor. Exp Cell Res 2001; 264: 29-41.

32. Thompson C. Apoptosis in the pathogenesis and treatment of disease. Science 1995; 267: 1456-62.

33. Fadeel B, Orrenius S. Apoptosis: a basic biological phenomenon with wide-ranging implications in human disease. J Intern Med 2005; 258: 479-517.

34. Campbell NA, Reece JB. Biology. San Francisco, USA: Pearson Benjamin Cummings; 2005.

35. Haupt S, Berger M, Goldberg Z, Haupt Y. Apoptosis - the p53 network. J Cell Sci 2003; 116: 4077-85.

36. Weller M, Kleihues P, Dichgans J, Ohgaki H. CD95 ligand: lethal weapon against malignant glioma? Brain Pathol 1998; 8: 285-93.

37. Komada Y, Zhou YW, Zhang XL, Chen TX, Tanaka S, Azuma E, Sakurai M. Fas/APO-1 (CD95)-mediated cytotoxicity is responsible for the apoptotic cell death of leukaemic cells induced by interleukin-2-activated $\mathrm{T}$ cells. Br J Haematol 1997; 96: $147-57$.

38. Blagosklonny MV. Mitotic arrest and cell fate: why and how mitotic inhibition of transcription drives mutually exclusive events. Cell Cycle 2007; 6: 70-4.

39. Prolla TA, Christie DM, Liskay RM. Dual requirement in yeast DNA mismatch repair for MLH1 and PMS1, two homologs of the bacterial mutL gene. Mol Cell Biol 1994; 14: 407-15.

40. Seifert M, Reichrath J. The role of the human DNA mismatch repair gene hMSH2 in DNA repair, cell cycle control and apoptosis: implications for pathogenesis, progression and therapy of cancer. J Mol Histol 2006; 37: 301-7.

41. Shiloh Y. ATM (ataxia telangiectasia mutated): expanding roles in the DNA damage response and cellular homeostasis. Biochem Soc Trans 2001; 29: 661-6.

42. Hartman AR, Ford JM. BRCA1 and p53: compensatory roles in DNA repair. J Mol Med 2003; 81: 700-7.

43. Nakanishi K, Taniguchi T, Ranganathan V, New HV, Moreau LA, Stotsky M, Mathew CG, Kastan MB, Weaver DT, D'Andrea AD. Interaction of FANCD2 and NBS1 in the DNA damage response. Nat Cell Biol 2002; 4: 913-20.

44. Schmutte C, Baffa R, Veronese LM, Murakumo Y, Fishel R. Human thymine-DNA glycosylase maps at chromosome 12q22-q24.1: a region of high loss of heterozygosity in gastric cancer. Cancer Res 1997; 57: 3010-5.

45. Hardeland U, Bentele M, Lettieri T, Steinacher R, Jiricny J, Schär P. Thymine DNA glycosylase. Prog Nucleic Acid Res Mol Biol 2001; 68: 235-53.

46. Fromme JC, Banerjee A, Verdine GL. DNA glycosylase recognition and catalysis. Curr Opin Struct Biol 2004; 141: 43-9.

47. Hollstein M, Sidransky D, Vogelstein B, Harris CC. p53 mutations in human cancers. Science 1991; 253: 49-53.

48. Greenblatt MS, Bennett WP, Hollstein M, Harris CC. Mutations in the p53 tumor suppressor gene: clues to cancer etiology and molecular pathogenesis. Cancer Res 1994; 54: 4855-78.

49. Schmutte C, Yang AS, Nguyen TT, Beart RW, Jones PA. Mechanisms for the involvement of DNA methylation in colon carcinogenesis. Cancer Res 1996; 56: 2375-81.

50. Sved J, Bird A. The expected equilibrium of the CpG dinucleotide in vertebrate genomes under a mutation model. Proc Nat Acad Sci USA 1990; 87: 4692-6.

51. Kim EJ, Um SJ. Thymine-DNA glycosylase interacts with and functions as a coactivator of p53 family proteins. Biochem Biophys Res Commun 2008; 377: 838-42.

52. Yoshida BA, Sokoloff MM, Welch DR, Rinker-Schaeffer CW. Metastasis-suppressor genes: a review and perspective on an emerging field. J Natl Cancer Inst 2000; 92: 1717-30.

53. Ohtaki T, Shintani Y, Honda S, Matsumoto H, Hori A, Kanehashi K, Terao Y, Kumano S, Takatsu Y, Masuda Y, Ishibashi Y, Watanabe T, Asada M, Yamada T, Suenaga M, Kitada C, Usuki S, Kurokawa T, Onda H, Nishimura O, Fujino M. Metastasis suppressor gene KiSS-1 encodes peptide ligand of a G-protein-coupled receptor. Nature 2001; 411: 613-7.

54. Hori A, Honda S, Asada M, Ohtaki T, Oda K, Watanabe T, Shintani Y, Yamada T, Suenaga M, Kitada C, Onda H, Kurokawa T, Nishimura O, Fujino M. Metastin suppresses the motility and growth of $\mathrm{CHO}$ cells transfected with its receptor. Biochem Biophys Res Commun 2001; 286: 958-63.

55. Kotani M, Detheux M, Vandenbogaerde A, Communi D, Vanderwinden JM, Le Poul E, Brézillon S, Tyldesley R, Suarez-Huerta N, Vandeput F, Blanpain C, Schiffmann SN, Vassart G, Parmentier M. The metastasis suppressor gene KiSS-1 encodes kisspeptins, the natural ligands of the orphan $\mathrm{G}$ protein-coupled receptor GPR54. J Biol Chem 2001; 276: 34631-6.

56. Meehan WJ, Welch DR. Breast cancer metastasis suppressor 1: update. Clin Exp Metastasis 2003; 20: 45-50.

57. Meehan WJ, Samant RS, Hopper JE, Carrozza MJ, Shevde LA, Workman JL, Eckert KA, Verderame MF, Welch DR. Breast cancer metastasis suppressor 1 (BRMS1) forms complexes with retinoblastoma-binding protein 1 (RBP1) and the $\mathrm{mSin} 3$ histone deacetylase complex and represses transcription. J Biol Chem 2004; 279: 1562-9.

58. Gomis-Rüth FX, Maskos K, Betz M, Bergner A, Huber R, Suzuki K, Yoshida N, Nagase H, Brew K, Bourenkov GP, Bartunik H, Bode W. Mechanism of inhibition of the human matrix metalloproteinase stromelysin-1 by TIMP-1. Nature 1997; 389: 77-81.

59. Kruger A, Sanchez-Sweatman OH, Martin DC, Fata JE, Ho AT, Orr FW, Ruther U, Khokha R. Host TIMP-1 overexpression confers resistance to experimental brain metastasis of a fibrosarcoma cell line. Oncogene 1998; 16: 2419-23.

60. Hojilla CV, Mohammed FF, Khokha R. Matrix metalloproteinases and their tissue inhibitors direct cell fate during cancer development. Br J Cancer 2003; 89: 1817-21.

61. Mitchell DC, Stafford LJ, Li D, Bar-Eli M, Liu M. Transcriptional regulation of KiSS-1 gene expression in metastatic melanoma by specificity protein- 1 and its coactivator DRIP-130. Oncogene 2007; 26: 1739-47.

62. Dong JT, Lamb PW, Rinker-Schaeffer CW, Vukanovic J, Ichikawa T, Isaacs JT, Barrett JC. KAI1, a metastasis suppressor 
gene for prostate cancer on human chromosome 11p11.2. Science 1995; 268: 884-6.

63. Mashimo T, Watabe M, Hirota S, Hosobe S, Miura K, Tegtmeyer PJ, Rinker-Shaeffer CW, Watabe K. The expression of the KAI1 gene, a tumor metastasis suppressor, is directly activated by p53. Proc Natl Acad Sci USA 1998; 95: 11307-11.

64. Zhang XA, He B, Zhou B, Liu L. Requirement of the p130CAS-Crk coupling for metastasis suppressor KAI1/CD82-mediated inhibition of cell migration. J Biol Chem 2003; 278: 27319-28. 